\title{
A Study on the Feedback of College English Dynamic Classified Teaching Effect
}

\author{
Lei Zhao \\ Faculty of Foreign Languages, Huaiyin Institute of Technology, Huai'an, China; \\ Lyceum of the Philippines University, Cavite, The Philippines
}

\begin{abstract}
This paper makes a combination of qualitative and quantitative research methods in the form of a questionnaire and interview to collect the students' feedback, which can be used for future designs of college students' cultivation. The results show that: first, in CET-4, the English proficiency of students in Category A is significantly better than that in Category B. Second, Category A has a more positive attitude towards classification criteria, curriculum, teaching materials and dynamic setting, while Category B shows more negative attitudes. With regard to the purpose, necessity and effect of classified teaching, Category $A$ and Category B have basically the same attitude, and most of them choose to be partially affirmed, indicating that the classified teaching model is positive on the whole, but it has its own shortcomings and needs to be improved. Third, classroom teaching should combine students' individual differences with common differences to strengthen the cultivation of students' comprehensive application ability.
\end{abstract}

Index Terms - college English, dynamic classified teaching model, feedback research

\section{INTRODUCTION}

As early as in 2016, Professor Wang Shouren (2016) made a key interpretation of the forthcoming College English Teaching Guide. His article not only expounds the development process and basic principles of the guide, but also explains and interprets college English curriculum value, teaching objectives, curriculum system, teaching evaluation, teaching methods and means, teacher development and other related issues for promoting college English teaching reform and improving the quality of college English teaching.

In September 2017, the Ministry of Education published the College English Teaching Guide (hereinafter referred to as the "Teaching Guide"). The Teaching Guide clearly points out that the goal of college English teaching can be divided into three levels: basic, medium and advanced, according to the current situation of basic education, higher education and social development in our country. There is no doubt that the arrangement of grading objectives provides colleges and universities enough space for the flexibility and openness of curriculum setting, and is conducive to the implementation of college English teaching reform to meet the individual needs of colleges, departments and students. In fact, before this, many colleges and universities have successively formulated and implemented the college English classified Teaching Model (Grade-teaching Mode) in line with their own school-running orientation, college types and talent-training goals. At present, according to the search terms of CNKI, there are three main terms for college English classified teaching: graded teaching, classified teaching and hierarchical teaching. In order to unify the title and avoid unnecessary name confusion, this paper will uniformly use the name "classified teaching". In China, the classified teaching mode of college English has been implemented for more than ten years. Throughout its research history, it mainly focuses on the theoretical basis, reflection on the pros and cons, exploration of new modes and so on, but there is not much feedback research on the model itself. This paper makes a combination of qualitative and quantitative research methods in the form of a questionnaire and interview to collect the students' feedback, which can be used for future designs of college students' cultivation.

\section{THEORETICAL BASIS}

Dynamic Classified Teaching

a) Connotation

Exactly speaking, the word "dynamic" in dynamic classification teaching should come from the Dynamic Systems Theory (DST). The main point of this theory is that the main performance of dynamic systems changes with time. Since then, in the 1970s, Larsen-Freeman initiated the study of DST in the field of applied linguistics. "She argues that language development is a dynamic and complex process, which lays a theoretical foundation for the study of DST in the field of applied linguistics" (cited from Ma Ruijuan, 2013). So what is classified teaching? The so-called classified teaching refers to a form of teaching organization which is divided into different categories based on learners' English proficiency level and subject achievement. Classified teaching is a systematic project, which involves all aspects of personnel training. Microscopically speaking, the essence of dynamic classified teaching is dynamic management on the basis of classified teaching, which has the characteristics of the combination of classification and dynamic.

b) Previous Theoretical Research 
In the theoretical exploration of classified teaching, the theory mostly expounded by domestic scholars (Li Jiongying \& Dai Xiuzhen 2001; Wang Haijie 2004; Deng Sufen 2009, etc.) is The Language Input Hypothesis Theory (1982) put forward by the American applied linguist Krashen, who defined the learners' current state of language knowledge as $\mathrm{i}$ and the next stage of their language development as $i+1$. In other words, only when learners acquire understandable language input can they acquire the language. It can be seen that understandable language input is the key to language acquisition, and the greatest significance of classified teaching is to let students accept as much understandable knowledge as possible. Secondly, some scholars (such as Wang Dingquan 2008; Lu Zhe 2010, etc.) use Constructivism Theory as the theoretical basis of classified teaching. Constructivist Learning Theory emphasizes learners' initiative and construction in the process of learning, distinguishes primary learning from high-level learning, and criticizes that the teaching strategies of primary learning are unreasonably extended to higher-class learning in traditional teaching. It also puts forward cooperative learning, situation teaching and so on. The third one is the Humanistic Theory and the "learner-centered" theory. Schunk proposes that teaching is "a process in which teachers help students develop from a novice level to a master level" (Ke Yingen 2016). The theory of "humanism" emphasizes human responsibility, individual phenomenon and human growth, which is consistent with the goal of classified teaching.

c) Empirical Research

It is undeniable that classified teaching is a systematic project, which means that teachers should do a good job in every practical stage in the process of classified teaching. In the aspect of curriculum design of classified teaching, Liu Changjiang (2008) elaborates on the design, management and teaching process of dynamic appointment course, an English audio-visual course in Nanjing University of Aeronautics and Astronautics. Through the feedback questionnaire survey, the study found that: the satisfaction with dynamic appointment classes and face-to-face teaching in class are $70.21 \%$, which shows that most students are positive about this teaching model. In terms of classification standards, in order to overcome the disadvantages of the classified teaching model based on the results of the college entrance examination or the classified examination after entrance examination, Liu Yamin et al. (2009) put forward a plan to solve this problem: to construct a teaching model of "learning by skill", that is, according to the scores of listening and reading skills, students are divided into three categories: primary, medium, advanced. The author assumes that Liu Yamin's teaching model of "learning by skill" is reasonable, because the goal of college English teaching is to strengthen the cultivation of college students' English comprehensive application ability, which is in accordance with the College English Syllabus, especially the cultivation of listening and speaking ability. In fact, many students are lack of listening and speaking ability, and there is a phenomenon of uneven development of listening, speaking, reading and writing in China. The teaching mode of "learning by skill" has solved this problem to a certain extent. Of course, we believe that its disadvantages are also very obvious, for example, the formulation of teaching plans and training programs may become more tedious, classified classes are only temporary, students lack a sense of belonging, sense of honor and disgrace, and so on. As explained by Liu Zehua et al. (2015): Classified teaching ignores students' emotional factors and is not conducive to students' cooperative learning. Therefore, he calls on College English Teaching Administrators to use empirical research to reflect the actual effects of classified teaching models. It is a pity that there are not many existing research results on the feedback of classified teaching effect. In terms of feedback on the effect of classified teaching, Jia Rongxiang et al. (2008) conducted a survey on English learning among non-English majors in Category B of Beijing Institute of Architecture and Engineering in the form of questionnaires and individual interviews. We believe that only the investigation and analysis of the students in Category B is not comprehensive and objective to evaluate the effect of classified teaching. It is no exaggeration to say that the objective and accurate evaluation and analysis of the teaching effect of classification is related to the dynamic changes of every student's English learning.

\section{Methodology}

\section{A. Cultivation Plan and Curriculum Setting}

Dynamic classified teaching model has been implemented for the freshmen in Huaiyin Institute of Technology since 2016. The freshmen were comprehensively classified into two categories according to their English scores in the Gaokao (College Entrance Examinations) and classified examination scores (except English majors, fine arts majors and separated enrollment students). Category A is a high-level group of learners and category B is a general-level group of learners. Under the guidance of the syllabus, different teaching objectives, contents, methods and different evaluation systems have been designed and used (as shown in Table 1). 
TABLE 1:

\begin{tabular}{|c|c|c|c|c|}
\hline & $\begin{array}{l}1^{\text {st }} \text { semester } 3 \\
\text { compulsory } \\
\text { credits }\end{array}$ & $\begin{array}{l}\text { CULTI } \\
2^{\text {nd }} \text { semester: } 3 \\
\text { compulsory } \\
\text { credits }\end{array}$ & $\begin{array}{l}\text { ATION PLAN OF COLLEGE ENGLISH } \\
3^{\text {rd }} \text { semester } 2 \text { compulsory credits + } \\
2 \text { optional credits } \\
\text { College English III (Integrated) is } \\
\text { required in Category A and Category B }\end{array}$ & $\begin{array}{l}4^{\text {th }} \text { semester } \\
2 \text { selective credits }\end{array}$ \\
\hline Category A & $\begin{array}{l}\text { College } \\
\text { English } \\
\text { Book } 1\end{array}$ & $\begin{array}{l}\text { College } \\
\text { English Book } 2\end{array}$ & $\begin{array}{l}\text { An overview of English-speaking } \\
\text { countries; } \\
\text { Academic English audio-visual listening } \\
\text { and speaking; } \\
\text { Translation practice and appreciation } \\
\text { (one of the three) }\end{array}$ & $\begin{array}{l}\text { Business English; } \\
\text { Academic English reading; } \\
\text { Advanced English Reading } \\
\text { (Postgraduate } \\
\begin{array}{l}\text { examination) (one of the } \\
\text { three) }\end{array}\end{array}$ \\
\hline Category B & $\begin{array}{l}\text { College } \\
\text { English } \\
\text { Book } 1\end{array}$ & $\begin{array}{l}\text { College } \\
\text { English Book } 2\end{array}$ & $\begin{array}{l}\text { College English III (English } \\
\text { audio-visual listening and speaking); } \\
\text { An overview of English-speaking } \\
\text { countries; } \\
\text { A Survey of Chinese Culture (English } \\
\text { edition) } \\
\text { (one of the three) }\end{array}$ & $\begin{array}{l}\text { College English IV } \\
\text { (Integrated); } \\
\text { Intercultural communication; } \\
\text { Advanced English Reading } \\
\text { (one of the three) }\end{array}$ \\
\hline
\end{tabular}

According to the cultivation plan, we also made correspondent curriculum (as shown in Table 2). In the first two semesters, both Category A and Category B are encouraged to focus on the basic skills development. In other words, the aim is to lay a good foundation for them to pass CET-4 and CET-6 smoothly. The third and fourth semesters are carried out in the way of the combination of comprehensive courses and follow-up courses, whose purpose is to pave the way for their further learning, at the same time, to well expand the horizons of learners and pay attention to personalized interests and hobbies. Among them, 8 credits are compulsory and 4 credits are elective.

TABLE 2

CURRICULUM SETTING OF FOUR SEMESTERS

\begin{tabular}{|c|c|c|c|c|}
\hline Category & Teaching objectives & Teaching content & Teaching method & Assessment system \\
\hline $\begin{array}{l}\text { Category } \\
\text { A }\end{array}$ & $\begin{array}{l}\text { Cultivate innovative } \\
\text { talents; prepare for } \\
\text { further study. }\end{array}$ & $\begin{array}{l}\text { Strengthen } \\
\text { comprehensive ability } \\
\text { training; increase } \\
\text { difficulty and depth. }\end{array}$ & $\begin{array}{l}\text { Heuristic teaching; } \\
\text { encourage } \\
\text { personalized } \\
\text { learning methods. }\end{array}$ & $\begin{array}{l}\text { Formative assessment-classroom } \\
\text { activity records, after-class self-study } \\
\text { records, interviews, etc. } \\
\text { Final assessment-final exams, four or } \\
\text { six proficiency tests. }\end{array}$ \\
\hline $\begin{array}{l}\text { Category } \\
\text { B }\end{array}$ & $\begin{array}{lr}\text { Train } & \text { applied } \\
\text { talents; prepare for } \\
\text { professional } & \text { study } \\
\text { and } & \text { future } \\
\text { employment. } & \end{array}$ & $\begin{array}{l}\text { Tamp the basic } \\
\text { knowledge, give } \\
\text { priority to reading and } \\
\text { writing, } \\
\text { appropriately and } \\
\text { strengthen the training } \\
\text { of listening and } \\
\text { speaking. }\end{array}$ & $\begin{array}{l}\text { Task-based } \\
\text { teaching; encourage } \\
\text { mutual learning and } \\
\text { group learning. }\end{array}$ & $\begin{array}{l}\text { Formative assessment-classroom } \\
\text { activity records, after-class self-study } \\
\text { records, interviews, etc. } \\
\text { Final assessment-final exam, CET-4 or } \\
\text { CET-6. }\end{array}$ \\
\hline
\end{tabular}

In order to promote the healthy development of students' personality and avoid the shortcomings of classified teaching itself. For example, students in Category A tend to breed pride, and students in category B with poor ability will have a sense of inferiority. At the end of each semester, teachers make a dynamic classification according to the results of learners' comprehensive evaluation in this semester. Learners in Category A may be relegated to Category B because of poor comprehensive evaluation results. In the same way, Learners in Category B will also be promoted to Category A because of their excellent performance in this semester.

\section{B. Research Participants}

The survey was conducted in March 2019. The participants were freshmen from Category A and Category B of 2018 computer engineering majors and Chemical Engineering majors of Huaiyin Institute of Technology. Huaiyin Institute of Technology also recruits students outside Jiangsu Province, so this survey also pays special attention to the feedback of students outside the province. For the college entrance examination English scores of students outside the province, this study has also carried out the corresponding conversion. Through statistical analysis, we know that the English scores of Category A in the College entrance examination are significantly better than those of Category B. the average score of Category A and B is 84.3 and 78.2 respectively (as shown in Table 3). Therefore, we can think that the purpose of classified teaching through the English scores of the college entrance examination in Huaiyin Institute of Technology is clear, that is, to implement the differentiated classified teaching model.

TABLE 3

\begin{tabular}{|c|c|c|c|c|c|}
\hline & & BACKGROUND & ATION OF PARTIC & & \\
\hline Category & Gender & Inside Jiangsu & Outside Jiangsu & subtotal & total \\
\hline \multirow{2}{*}{ Category A } & Male & 61 & 1 & 62 & \multirow{2}{*}{107} \\
\hline & Female & 38 & 7 & 45 & \\
\hline \multirow{2}{*}{ Category B } & Male & 63 & 15 & 78 & \multirow{2}{*}{115} \\
\hline & Female & 29 & 8 & 37 & \\
\hline
\end{tabular}


From the distribution of students outside the province, we can see that there are only 8 non-provincial students in Category A, accounting for $7.5 \%$ of the total number of Class A, which is a relatively small number, while Category B has 23 students from outside Jiangsu province, accounting for $20 \%$, which is a relatively high proportion.

\section{Research Methods}

This study is carried out in the form of a questionnaire, and the survey results are analyzed quantitatively and qualitatively. A total of 241 questionnaires were sent out, including 107 valid questionnaires and 9 invalid questionnaires in Class A class, 115 valid questionnaires and 10 invalid questionnaires in Class B class. The questionnaire consists of 15 multiple choice questions (each with three options) and one subjective question. Through the comparative analysis of the questionnaire results of Class A and Class B, the reasons behind them are analyzed. For the college entrance examination English scores and CET-4 test results and other data statistics, we use the statistical software SPSS16.0 for statistical analysis.

\section{Research Questions}

a) Is there a significant difference in CET-4 scores between Class A and Class B? If there is a significant difference, what is the reason?

b) Is there any significant difference in the answers to the questionnaire between Class A and Class B, and what are their feedback? What is the reason for the difference?

c) What are the results of the interviews with the two types of classes? What are their suggestions or opinions on dynamic classification teaching?

\section{RESUltS AND DisCUSSION}

In terms of CET-4 scores, from the descriptive statistical results, the average score of Class A is 484.3 , mainly due to the fact that 88 students' scores are between 425 and 599, accounting for $82.2 \%$, and the scores are relatively concentrated. At the same time, the proportion of students with scores below 425 is very small, only $16.8 \%$. On the contrary, the average score of class B is only 406, which is lower than the passing line of 425 . The main reason is that more than half of the students have a score below 425, accounting for a relatively high score of $64.3 \%$, while only 41 students have a score higher than 425 (including 425), accounting for only 35.6\%. (as shown in Table 4)

TABLE 4

THE DesCRIPTIVE Statistical Results of CATEGORY A AND B

\begin{tabular}{llllllll} 
Category & average & $\begin{array}{l}\text { St. } \\
\text { Deviation }\end{array}$ & St. error & $<425$ & $425-499$ & $500-599$ & $\geq 600$ \\
\hline $\begin{array}{l}\text { Category } \\
107\end{array}$ & $\mathrm{~A}_{484.3}$ & 50.837 & 4.915 & $18 / 16.8 \%$ & $47 / 43.9 \%$ & $41 / 38.3 \%$ & $1 / 0.9 \%$ \\
\hline $\begin{array}{l}\text { Category } \\
115\end{array}$ & $\mathrm{~B}_{406.06}$ & 63.340 & 5.906 & $74 / 64.3 \%$ & $34 / 29.6 \%$ & $7 / 6 \%$ & $0 / 0$ \\
\hline
\end{tabular}

In terms of the independent sample t-test, it requires that the two groups of population variances must be equal. Therefore, first of all, we need to look at the test of homogeneity of variance (that is, Levene test). The statistical results show that the significance probability of Levene test is low, that is, Sig.=.226, is greater than 0.05, indicating that there is a significant difference in the variance of English scores in the college entrance examination between the two groups, so it is necessary to use the corrected t-test, that is, to check the data of the line "Equal variances assumed" as the result of the t-test. It can be seen that the significant level of the $t$ value of the two groups in the college entrance examination English score is 0.000 , far less than 0.05 , and the $95 \%$ confidence interval of the mean difference does not include 0 , indicating that there is a significant difference between class A and class B (as shown in Table 5). Based on this, it can be concluded that the English proficiency of Class A students is significantly better than that of Class B students.

TABLE 5

\begin{tabular}{|c|c|c|c|c|c|c|c|}
\hline \multicolumn{8}{|c|}{$\begin{array}{c}\text { TABLE } 5 \\
\text { THE RESULT OF THE INDEPENDENT SAMPLE T-TEST }\end{array}$} \\
\hline & & $\mathrm{df}$ & & Mean & Std. & Error $95 \% \mathrm{Co}$ & of the Difference \\
\hline 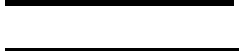 & $=\mathrm{t}$ & dI & (2-tailed) & Difference & Difference & Lower & Upper \\
\hline $\begin{array}{ll}\text { Equal variances } \\
\text { assumed }\end{array}$ & $\begin{array}{l}10.1 \\
0\end{array}$ & 220 & .000 & 78.238 & 7.744 & 62.976 & 93.500 \\
\hline $\begin{array}{l}\text { Equal variances } \\
\text { not assumed }\end{array}$ & $\begin{array}{l}10.1 \\
8\end{array}$ & 215 & .000 & 78.238 & 7.684 & 63.093 & 93.383 \\
\hline
\end{tabular}

To explore the reasons, there are the following aspects: first, there is a great disparity in the English foundation of students when they enter school, and class A is obviously better than class B. Second, after enrollment, the majority of male students in science and engineering colleges or universities may slacken their requirements on English learning, coupled with the fact that English is a "short-leg" subject, resulting in learning weariness. Third, the students who are assigned to Class B have a feeling of "inferior" psychologically. At the same time, the English foundation of the 
students around them is not very good, and the English learning atmosphere in the class is not strong. Undoubtedly, disadvantages of classified teaching mode are very obvious too. In order to learn more about their response to this teaching mode, a specially designed questionnaire and interview question have been adopted and used for them.

TABLE 6

COMPARISON OF THE RESUltS OF THE QUESTIONNAIRE BETWEEN CATEGORY A AND B

\begin{tabular}{|c|c|c|}
\hline $\begin{array}{l}\text { Totally } \\
\text { (A/B) }\end{array}$ & $\begin{array}{r}\text { agree Totally } \\
(\mathrm{A} / \mathrm{B})\end{array}$ & $\begin{array}{l}\text { I don't know / it doesn't } \\
\text { matter (A/B) }\end{array}$ \\
\hline $\begin{array}{l}\text { 3.Do you think the current English classification criteria (according } \\
\text { to the results of the college entrance examination and the classified } 67 / 38 \\
\text { examination) are reasonable? }\end{array}$ & $18 / 40$ & $22 / 37$ \\
\hline $\begin{array}{l}\text { 5.Do you think classified teaching has any influence on students' } \\
\text { learning enthusiasm? }\end{array}$ & $28 / 49$ & $21 / 35$ \\
\hline $\begin{array}{l}\text { 7.Does classified teaching management play a role in arousing } \\
\text { students' enthusiasm for learning and encouraging fair 59/46 } \\
\text { competition? }\end{array}$ & $17 / 33$ & $31 / 36$ \\
\hline 8.Is the classified class of college English attractive? & $31 / 60$ & $26 / 32$ \\
\hline $\begin{array}{l}\text { 9.Are you satisfied with the curriculum setting in classified } 62 / 39 \\
\text { teaching? }\end{array}$ & $15 / 29$ & $30 / 47$ \\
\hline $\begin{array}{l}\text { 11.Do you think the difficulty of the teaching materials currently } 78 / 71 \\
\text { used is appropriate? }\end{array}$ & $12 / 15$ & $17 / 29$ \\
\hline 12.Does the textbook reflect students' learning needs and interests? $36 / 36$ & $33 / 43$ & $38 / 36$ \\
\hline $\begin{array}{l}\text { 13.Classified teaching adopts rolling teaching management, that is, } \\
\text { "those who can go up, those who cannot go down". What do you 64/48 } \\
\text { think? }\end{array}$ & $18 / 40$ & $25 / 27$ \\
\hline 14. What is the impact of classified teaching on your psychology? $68 / 16$ & $12 / 40$ & $27 / 49$ \\
\hline $\begin{array}{l}\begin{array}{l}\text { 15.Does classified teaching bring you some psychological } \\
\text { pressure? }\end{array} \\
\end{array}$ & $43 / 46$ & $10 / 22$ \\
\hline $\begin{array}{l}\text { Totally } \\
\text { (A/B) }\end{array}$ & ${ }^{\text {agree }}$ Partly agree $(\mathrm{A} / \mathrm{B})$ & Totally disagree $(\mathrm{A} / \mathrm{B})$ \\
\hline $\begin{array}{l}\text { 1.Do you understand the purpose of classified college English } 8 / 12 \\
\text { teaching? }\end{array}$ & $76 / 72$ & $23 / 31$ \\
\hline $\begin{array}{l}\text { 2.Do you think it is necessary to teach college English by } 10 / 11 \\
\text { classification? }\end{array}$ & $81 / 79$ & $16 / 25$ \\
\hline $\begin{array}{l}\text { 4.Are you adapted to the current classified teaching of college } 15 / 9 \\
\text { English? }\end{array}$ & $83 / 83$ & $9 / 23$ \\
\hline $\begin{array}{l}\text { 6.Do you think the current classified teaching is helpful to improve } 24 / 10 \\
\text { your English learning performance? }\end{array}$ & $70 / 86$ & $13 / 19$ \\
\hline $\begin{array}{l}\text { 听 说 } \\
(\mathrm{A} / \mathrm{B})\end{array}$ & 能 力 综合能力 ( $\mathrm{A} / \mathrm{B})$ & $\begin{array}{l}\text { 英语过类考试能力 } \\
\text { (A/B) }\end{array}$ \\
\hline $\begin{array}{l}\text { 10. What aspects of classroom teaching should be strengthened in } 32 / 22 \\
\text { classified teaching? }\end{array}$ & $47 / 49$ & $28 / 44$ \\
\hline
\end{tabular}

In question I part, most of the students in Category A responded positively to the classified teaching mode and its effects. They believe, the classification standard is reasonable; Dynamic classification is conducive to arousing students' enthusiasm for learning; the curriculum setting is reasonable, and the difficulty of teaching materials is moderate. On the other hand, the answers of the students in Category B show more negative or indifferent attitude, which reflects that the students in Category B are tired of learning, and they are resistant to English learning and English courses. In addition, on the answers to questions 12 and 15, Category A and Category B have the same attitude. That is, the choice of teaching materials should fully meet the learning needs and interests of learners; the psychological pressure brought by dynamic classified teaching to the two categories is the same.

For the negative response of the students in Category B, there may be many reasons that can explain it well: First, as a freshman, he/she has not yet adapted to the new teaching model and learning environment, and their learning goal or orientation is not clear. The abilities of self-monitoring, autonomous learning and cooperative learning are weaker than those of Category A; second, classified classes are completely different from natural classes, which have obvious shortcomings, such as lack of sense of belonging and emotional support. What's more, classroom tasks can not be extended to extracurricular, and cooperative learning is hindered, because of the estranged relationship each other; third, long-term English learning has not made great progress, which made students from Category B feel discouraged and disappointed. Consequently, English learning becomes passive and passive. It is not difficult to see that the shortcomings of classified teaching are obvious, that is, ignoring the emotional factors of Category B students, making them think that they are treated differently and feel discriminated against in English learning. These factors dampen their enthusiasm for learning English to a great extent and have a backwash effect on their long-term English learning. 
In the question II part, the opinions of Category A and Category B are basically the same, and most of the students partially affirmed the purpose, necessity and effect of classified teaching mode, which shows that many students have little knowledge of the real purpose and process of classified teaching, and they are also vague about their two-year college English planning. At the same time, classified teaching mode itself also needs to be improved, such as the optimization of training programs, the rationality of evaluation and assessment and so on. Taking the teaching goal in the training program as an example, Category A is to be trained innovative talents and be prepared for further study. So the question comes: Are students who are good at English innovative talents and reserve forces for further study? Do students who are not good at English have to be trained into applied talents? It is a bit far-fetched to judge the future of students by their English proficiency. In other words, students in Category B may also become innovative talents in their own professional fields, while students in Category A may also give up further studies and choose employment to become applied talents.

For the questions in the III category, 47 and 49 students in Category A and Category B respectively think that classroom teaching should pay attention to the cultivation of students' comprehensive ability, and half of them emphasize listening and speaking ability and the ability of passing English exams. This shows that students from both Category A and Category B have the same needs for the cultivation of comprehensive English application ability. Some students have weak abilities on listening and speaking, but they have strong ability to pass the examination, which is commonly known as "Dumb English"; Some students are good at oral English and have no problems in daily dialogue, but their grammar foundation is weak and their vocabulary is insufficient, which finally leads to their failure in English exams and a sense of frustration. (as shown in Table 6)

TABLE 7
SOME FEEDBACK OF CATEGORY A AND B

Student 1A: Some texts are boring and uninteresting, and some teachers pay less attention on teaching
methods, so gradually I lost my interest!
Student 2A: We are from different classes and majors, so we don't know each other, which is bad for us to
participate in the group discussion and role-playing in class actively.
Student 3A: I have passed CET-4, and the teacher's class is not related to CET-4 or CET-6, so I am not
interested.

From the above interview excerpts (as shown in Table 7), we can find some problems in classified teaching: For example, whether the follow-up courses can be moved forward for those freshmen who pass CET-4 in the first semester, who must own a sense of pride and complacency. The follow-up courses will stimulate their interest in learning. In addition, the large class size is also one of the actual problems. The current classified class size is basically between over 50 and 60 students, some even more, coupled with some teachers' lack of classroom control ability, which is bound to affect the teaching effect; finally, it is also reflected in the lack of cooperative learning ability of learners. College English learning, which emphasizes autonomous learning, self-monitoring and teamwork, is completely different from junior and senior high school learning. Due to the continuous deepening of college English teaching reform in recent years, many colleges and universities have reduced the class hours of college English, which means that the number of English course of each semester is correspondingly reduced. It goes without saying, students should be put more emphasis on autonomous learning and cooperative learning after class, because limited classroom learning is far from enough.

\section{CONCLUSION}

Through the feedback of the questionnaire, we can see that its advantages and disadvantages are clear. As far as English learning is concerned, dynamic classification teaching fully takes into account the teaching concept of "teaching students in accordance with their aptitude" and arouses students' learning enthusiasm to a certain extent. At the same time, we should see its shortcomings. Many colleges and universities have biases in their understanding of "teaching requirements". They blindly think that this is the basis of classified teaching, but in fact, judging from the results of the survey, the needs of students vary from person to person, but one thing is clear: How to meet the individual learner's needs on language learning is one of the most important issues that we educators and schools must think about.

\section{REFERENCES}

[1] Deng Sufen. (2009). The Stage Teaching of English Extensive Reading from the Perspective of I + 1 Theory. Journal of Hunan Medical University. Vol. 11, No.1, 240-241.

[2] Jia Rongxiang, Du Miao, Li Zhiyuan. (2008). Investigation and Analysis on the Learning Effects of Students in Class B in English Classified Teaching and its Enlightenment. Journal of Capital Normal University. Supplement. 123-128.

[3] Ke Yinggen. (2016). A Study on the Reform Process and Problems of College English Classified Teaching. Jiangsu Higher Education. 4, 67- 70 . 
[4] Krashen, S. D. (1982). Principles and Practice in Second Language Acquisition. Oxford: Pergamon.

[5] Li Jiongying \& Dai Xiuzhen. (2001). On the Language Input of College English Classified Teaching from the Perspective of I+1 Theory. Foreign Language Teaching in Shandong. 1, 54-58.

[6] Liu Changiiang. (2008). A School-based Study of "dynamic lesson appointment" from the Perspective of Personalized Teaching. Foreign language and Foreign language Teaching. 11, 20-24.

[7] Liu Yamin \& Zhu Zhengcai \& Chang Hui. (2009). A New probe into the Reform of College English Classified Teaching Mode. Foreign Language World. 4, 23-29.

[8] Liu Zehua \& Shen Kaizhong. (2015). Reflection and Countermeasures of Classified College English Teaching in China's Universities. China University Teaching. 12, 36-41.

[9] Lu Zhe \& Li Dan. (2010). English Classified Teaching Model Based on Constructivist Learning Theory. Journal of Hengyang Normal University. Vol. 31, No. 2, 144-147.

[10] Ma Ruijuan. (2013). A study of English Teaching Model Based on Ecolinguistics and Dynamic System Theory. Educational Theory and Practice. Vol. 33, No. 27. 47--49.

[11] Wang Dingquan. (2008). A Study on the Theory and Feasible Operation of College English Classified Teaching. Journal of Southwest University for Nationalities. 10, 149-150.

[12] Wang Haijie. (2004). Krashen's Second Language Acquisition Theory and Classified Teaching of College English Listening. Journal of Changsha University. Vol. 18, No. 3, 118-120.

[13] Wang Shouren. (2016). An Interpretation of College English Teaching Guide. Foreign Language World. 3, 2-10.

Lei Zhao was born in Huai'an city, China, in 1981. He received his Master's Degree in applied linguistics in Nanjing Tech University, China in 2012. He is now studying for PH.D. in English language in Lyceum of the Philippines University.

$\mathrm{He}$ is a senior lecturer in the Faculty of Foreign Languages in Huaiyin Institute of Technology, Jiangsu, China. His research interest is cognitive Linguistics, metaphor translation, and second language acquisition. 